\section{Germination Characteristics of Three Warm-season Turfgrasses Subjected to Matriconditioning and Aging}

\author{
Gokhan Hacisalihoglu ${ }^{1}$
}

ADDITIONAL INDEX WORDs. bahiagrass, bermudagrass, centipedegrass, seed, vigor

SUMMARY. Many warm-season turfgrass seeds have relatively poor germination percentages. Matriconditioning is a seed enhancement technique with a solid carrier and may be a practical solution to improve the germination characteristics of warmseason turfgrass. The objective of this study was to determine the effectiveness of matriconditioning on three nonaged and aged turfgrass cultivars: 'Pensacola' bahiagrass (Paspalum notatum), 'Princess' bermudagrass (Cynodon dactylon), and 'Common' centipedegrass (Evemochloa ophiuroides). Seeds were matriconditioned with a synthetic calcium silicate (MicroCel E) as a carrier and water at $30{ }^{\circ} \mathrm{C}$ for 5 days. Seed, carrier, and water ratio was $1 \mathrm{~g}, 0.5 \mathrm{~g}$, and $1.5 \mathrm{~mL}$, respectively. Matriconditioning increased final germination to $55 \%$ (bahiagrass), $90 \%$ (bermudagrass), and $70 \%$ (centipedegrass) compared with $92 \%$ in nontreated control seeds. Furthermore, matriconditioning decreased mean germination time $20 \%$ to $65 \%$ in all seeds compared with the nontreated control. Accelerated aging was induced by storing seeds for 0,7 , and 14 days at $42{ }^{\circ} \mathrm{C}$ and $95 \%$ relative humidity. Germination percentage decreased and mean germination time increased with the aging, especially after 14 days of aging treatment. These results suggest that matriconditioning is an effective technique to improve turfgrass seed performance.

$\mathrm{F}$ lorida is the nation's second leading state in lawn care services with annual $\$ 5$ billion impact and 84,000 jobs per year (Hodges and Mulkey, 2003). There are several warm-season turfgrasses established from seeds, including bahiagrass, bermudagrass, and centipedegrass (Trenholm et al., 2001). Bahiagrass is a low-maintenance turfgrass that is tolerant to salt and drought. Bermudagrass is a mediummaintenance lawngrass that is widely used as sports turf. Centipedegrass is a low-maintenance grass that is common on lawns, especially in northern Florida (Table 1).

Establishing a successful lawn requires good seed quality and subsequent seedling emergence (Trenholm et al., 2001). It has been shown that seed enhancements improve the performance of seeds as a result of increased synthesis of seed hor-

Biology Department, Florida A\&M University, 207 Jones Hall, 1530 S. M.L.K. Boulevard, Tallahassee, FL 32307

I gratefully appreciate the donation of seeds from J. Unruh (University of Florida, Milton, FL) and B. Kresin (Pennington Seed Inc., Orlando, FL), and donation of MicroCel E from World Minerals (Lompoc, CA). Thanks are also due to T. Katsvairo for technical help.

${ }^{1}$ Corresponding author and Assistant Professor of Biology. E-mail: gokhan.h@famu.edu. mones and enzymes (Taylor et al., 1998). For example, matriconditioning (MC), or priming seeds through solid carriers with low matric potentials, proved highly effective in improving germination of several vegetable seeds by allowing limited water to start the major metabolic events in seeds (Khan, 1992). MicroCel E (synthetic calcium silicate; World Minerals, Lompoc, CA) has been reported as a superb solid carrier for MC (Khan, 1992; Taylor et al., 1998). Khan et al. (1992) reported increased germination percentage (GP) and emergence of snap bean (Phaseolus vulgaris), carrot (Daucus carota), tomato (Solanum lycopersicum), and pepper (Capsicum annuum) when seeds were matriconditioned by MicroCel E only or combined with $\mathrm{GA}_{3}$. It has been reported that germination decreased with storage (Taylor et al., 1998). Furthermore, priming may accelerate the effect of seed aging. For example, primed lettuce (Lactuca sativa) seeds aged faster than control seeds under $45^{\circ} \mathrm{C}$ with $50 \%$ relative humidity $(\mathrm{RH})$ conditions (Hacisalihoglu et al., 1999) or $40{ }^{\circ} \mathrm{C}$ with $10 \% \mathrm{RH}$ (Tarquis and Bradford, 1992).

Few studies have been conducted on the enhancement of turfgrass seeds, and even fewer have tested MC as well as storage of turfgrass seeds. The objective of this study was to evaluate the effect of $\mathrm{MC}$ on warm-season turfgrass GP and mean germination time under optimum, 7- or 14-d accelerated aging conditions.

\section{Materials and methods}

$S$ EE D M A T ERIA L A N D MATRICONDITIONING. Seeds of 'Pensacola' bahiagrass, 'Princess' bermudagrass, and 'Common' centipedegrass were obtained from seed companies or institutions (Table 1 ) and stored at $6^{\circ} \mathrm{C}, 33 \% \mathrm{RH}$, and small batches were removed as needed. For MC, seeds were mixed with MicroCel $\mathrm{E}$ at different matric potentials by altering the water content of conditioning mixture. $\mathrm{MC}$ was carried out in $500-\mathrm{mL}$ glass jars by mixing $\mathrm{l} \mathrm{g}$ seeds, $0.5 \mathrm{~g}$ MicroCel E, and $1.5 \mathrm{~mL}$ distilled water at $30{ }^{\circ} \mathrm{C}$ for $5 \mathrm{~d}$. After $\mathrm{MC}$, seeds were washed for $20 \mathrm{~s}$ and dried back by air at $25{ }^{\circ} \mathrm{C}$ for $2.5 \mathrm{~h}$. The moisture content was determined by drying the seeds in an oven at $130{ }^{\circ} \mathrm{C}$ for $\mathrm{l} \mathrm{h}$.

Germination test. Four replications of 25 seeds were placed on filter paper (Whatman, Atlanta, GA) in 9-cm-diameter petri dishes moistened with $3 \mathrm{~mL}$ distilled water at $20 / 35^{\circ} \mathrm{C}$ (16-h dark/8-h light) as recommended by the Association of Official Seed Analysts (2002). Seed germination was counted daily until no further germination occurred for $4 \mathrm{~d}$. The mean germination time (MGT) was determined using the following equation:

\begin{tabular}{llll}
\hline $\begin{array}{l}\text { Units } \\
\text { To convert U.S. to SI, } \\
\text { multiply by }\end{array}$ & U.S. unit & SI unit & $\begin{array}{l}\text { To convert SI to U.S., } \\
\text { multiply by }\end{array}$ \\
\hline 29.5735 & $\mathrm{fl} \mathrm{oz}$ & $\mathrm{mL}$ & 0.0338 \\
2.5400 & inch $(\mathrm{es})$ & $\mathrm{cm}$ & 0.3937 \\
25.4000 & inch $(\mathrm{es})$ & $\mathrm{mm}$ & 0.0394 \\
28.3495 & $\mathrm{Oz}$ & $\mathrm{g}$ & 0.0353 \\
$\left({ }^{\circ} \mathrm{F}-32\right) \div 1.8$ & ${ }^{\circ} \mathrm{F}$ & ${ }^{\circ} \mathrm{C}$ & $\left(1.8 \times{ }^{\circ} \mathrm{C}\right)+32$
\end{tabular}


Table 1. Sources, uses, and cultivars of three warm-season turfgrass species used for seed germination, matriconditioning, and aging studies in Tallahassee, FL.

\begin{tabular}{|c|c|c|c|}
\hline Species & Cultivar & Seed source & Uses in Florida \\
\hline Bahiagrass & Pensacola & $\begin{array}{l}\text { Pennington Seed } \\
\text { Inc., Orlando, FL }\end{array}$ & Lawns \\
\hline Bermudagrass & Princess & $\begin{array}{l}\text { Seeds West } \\
\text { Inc., Yuma, AZ }\end{array}$ & Sports fields \\
\hline Centipedegrass & Common & $\begin{array}{l}\text { Forrester Farms, } \\
\text { Columbia, AL }\end{array}$ & Lawns \\
\hline
\end{tabular}
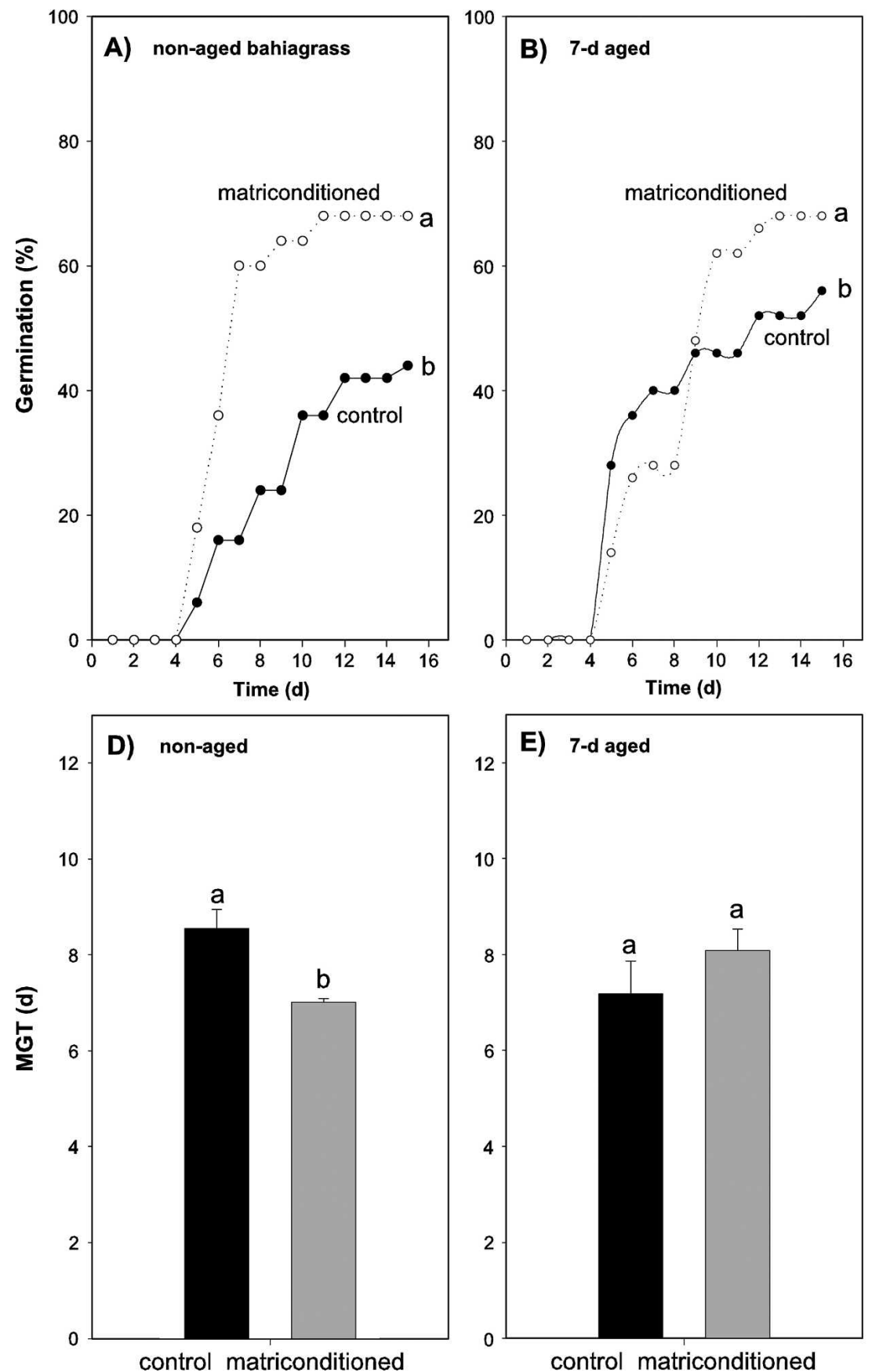

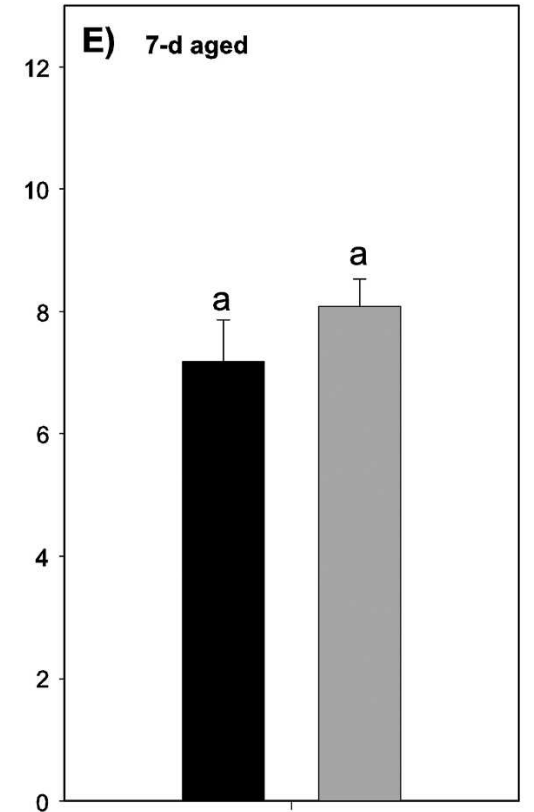

control matriconditioned
$\mathrm{MGT}=\Sigma(\mathrm{n} i \times \mathrm{t} i) / \Sigma \mathrm{n}$,

where $\mathrm{n} i$ was the number of newly germinated seeds at time of $t i$ after imbibing, and $\mathrm{n}=$ total number seeds emerged.

Accelerated aging test. The protocol for accelerating aging was carried out as described previously (Hacisalihoglu et al., 1999).
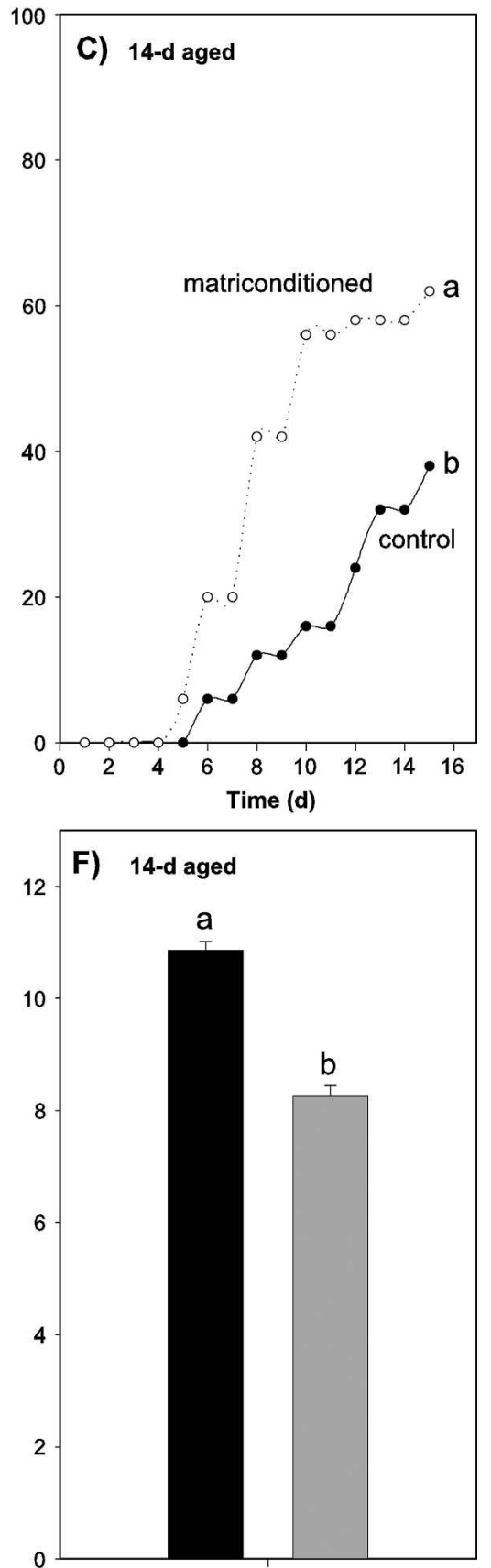

control matriconditioned

Fig. 1. Germination percentage and mean germination time (MGT) of 'Pensacola' bahiagrass seeds with three aging treatments. (A) Germination of nonaged seeds, (B) germination of seeds aged $7 \mathrm{~d}$, (C) germination of seeds aged $14 \mathrm{~d}$, (D) MGT of nonaged seeds, (E) MGT of seeds aged $7 \mathrm{~d}$, and (F) MGT of seeds aged $14 \mathrm{~d}$. Accelerated aging was induced by storing seeds for 0 , 7 , and $14 \mathrm{~d}$ at $42{ }^{\circ} \mathrm{C}\left(107.6^{\circ} \mathrm{F}\right)$ and $95 \%$ relative humidity. Within each box, lines or bars with the same letters are not significantly different at $P<0.05$. 

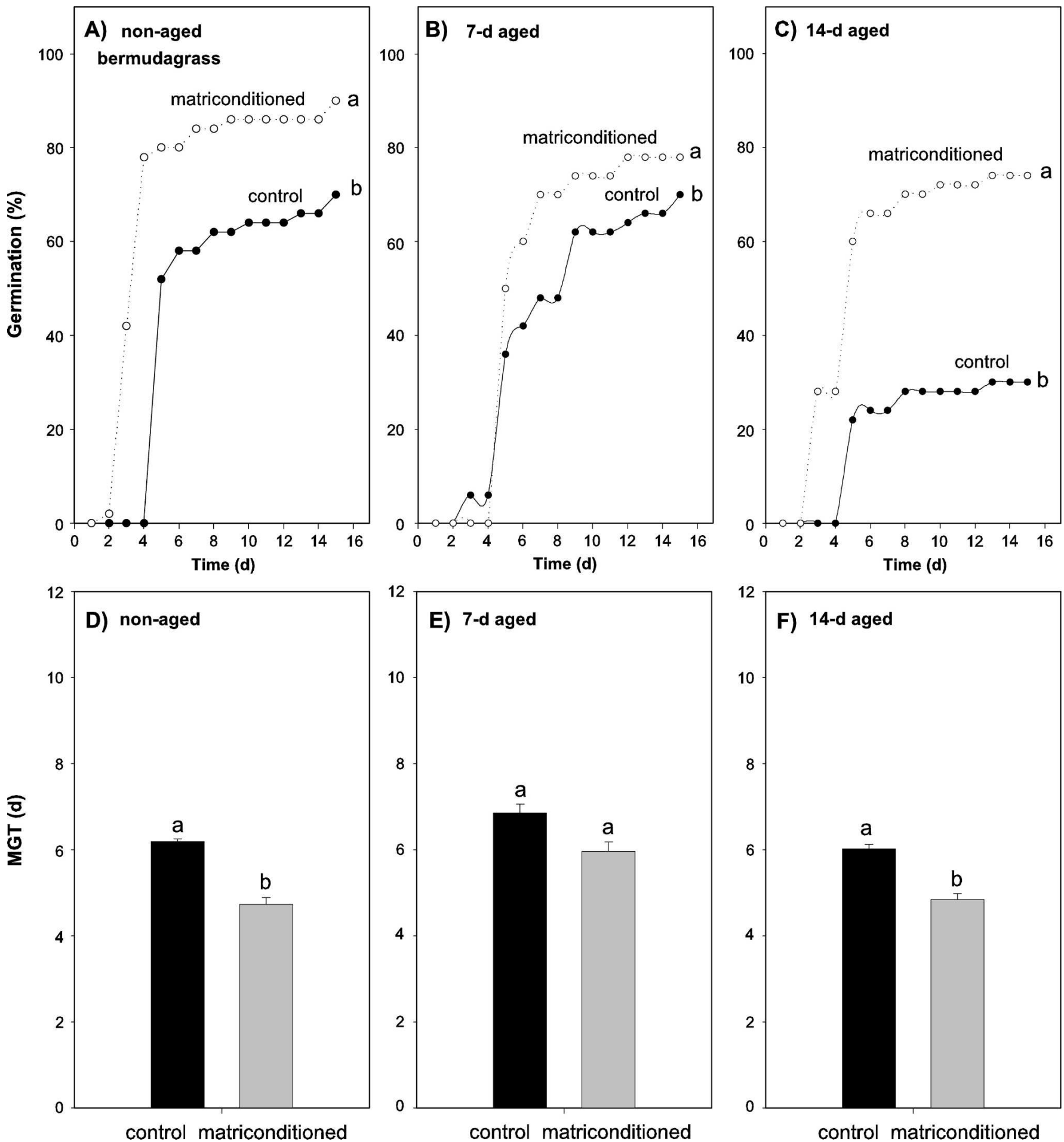

Fig. 2. Germination percentage and mean germination time (MGT) of 'Princess' bermudagrass seeds with three aging treatments. (A) Germination of nonaged seeds, (B) germination of seeds aged $7 \mathrm{~d},(\mathrm{C})$ germination of seeds aged $14 \mathrm{~d}$, (D) MGT of nonaged seeds, (E) MGT of seeds aged $7 \mathrm{~d}$, and (F) MGT of seeds aged $14 \mathrm{~d}$. Accelerated aging was induced by storing seeds for 0,7 , and $14 \mathrm{~d}$ at $42{ }^{\circ} \mathrm{C}\left(107.6^{\circ} \mathrm{F}\right)$ and $95 \%$ relative humidity. Within each box, lines or bars with the same letters are not significantly different at $P<0.05$.

Matriconditioned and nontreated control seeds were aged for 7 or $14 \mathrm{~d}$ at $42^{\circ} \mathrm{C}$ in magenta vessels $(77 \times$ $77 \times 97 \mathrm{~mm}$; Fisher Scientific, Suwanee, GA). Seeds were placed above the solution on a mesh sieve.
Relative humidity was maintained $\approx 95 \%$ as measured by a thermohygrometer (Fisher Scientific). After aging, seeds were removed from boxes and used in germination experiments.
EXPERIMENTAL DESIGN AND DATA ANALYsis. The experiments were set up in a completely randomized design with four replications. The experiment was repeated three times. Analysis of variance was used to determine 

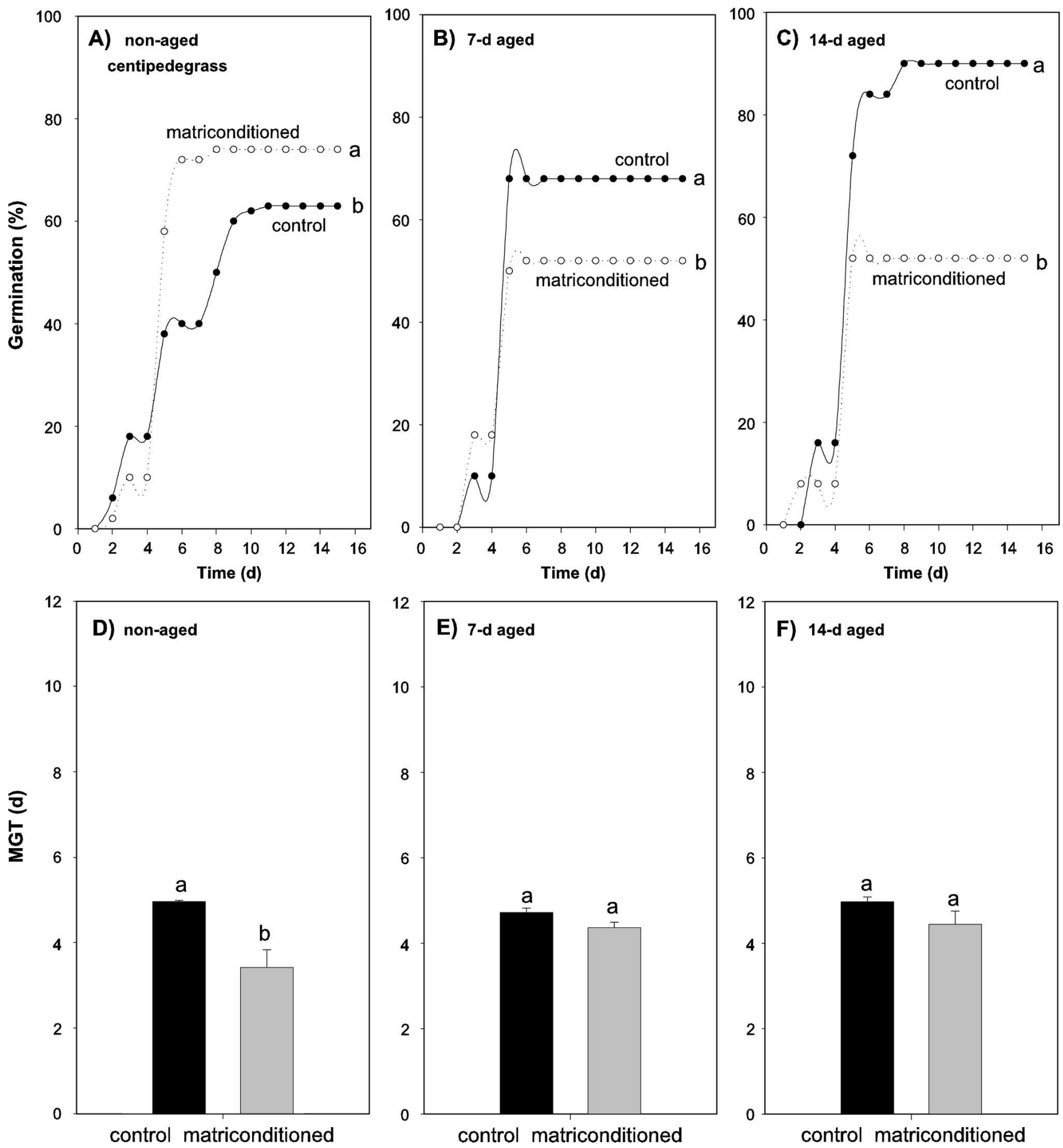

Fig. 3. Germination percentage and mean germination time (MGT) of 'Common' centipedegrass seeds with three aging treatments. (A) Germination of nonaged seeds, (B) germination of seeds aged $7 \mathrm{~d},(\mathrm{C})$ germination of seeds aged $14 \mathrm{~d}$, (D) MGT of nonaged seeds, (E) MGT of seeds aged $7 \mathrm{~d}$, and (F) MGT of seeds aged $14 \mathrm{~d}$. Accelerated aging was induced by storing seeds for 0,7 , and $14 \mathrm{~d}$ at $42{ }^{\circ} \mathrm{C}\left(107.6^{\circ} \mathrm{F}\right)$ and $95 \%$ relative humidity. Within each box, lines or bars with the same letters are not significantly different at $P<0.05$.

the effects of treatment using a general linear model procedure (SAS Institute, Cary, NC). The means were separated using least significant difference at $P<0.05$. The response between germination (percentage) and time (days) followed a nonlinear sigmoid (SPSS, Chicago). The equation used was $y=a / 1+e^{-[x-x 0 / 6]}$, where $y=$ germination, $a=$ slope, $X_{o}=$ germination elicits $50 \%$ response, $b=$ $\mathrm{y}$-intercept, and $x=$ time.

\section{Results}

\section{Matriconditioning} and germination

The effect of MC on the germination of turfgrass seeds is summarized in Figures 1-3 and Tables 2 
and 3. In all experiments, MC with MicroCel E was successful in increasing GP while decreasing MGT. In each cultivar studied, GP was higher (Figs. 1A, 2A, and 3A) and MGT was lower (Figs. 1D, 2D, and 3D) for matriconditioned seeds compared with nontreated control seeds.

BaHiagrass. Final GP increased $55 \%$ (from $44 \%$ to $68 \%$ ) in matriconditioned seeds compared with nonprimed control (Fig. 1A; Table 3). Furthermore, MC significantly reduced MGT (20\%) compared with nonprimed control seeds (Fig. ID).

Bermudagrass. Final GP increased $29 \%$ (from $70 \%$ to $90 \%$ ) in matriconditioned seeds compared with nonprimed control (Fig. 2A; Table 3 ). Furthermore, MC significantly reduced MGT (30\%) compared with nonprimed control seeds (Fig. 2D).

Centipedegrass. Final GP increased $10 \%$ (from $67 \%$ to $75 \%$ ) in matriconditioned seeds compared with nonprimed control (Fig. 3A; Table 3). Furthermore, MC significantly reduced MGT (65\%) compared with nonprimed control seeds (Fig. 3D).

\section{Response to aging}

Overall, GP decreased with increased aging duration. There were significant differences among turf- grass cultivars subjected to accelerated aging.

Bahiagrass. The 14-d aging treatment, but not 7 -d aging treatment, significantly decreased GP. However, matriconditioned seeds had $21 \%$ (7-d aged) and 63\% (14-d aged) higher final GP compared with nontreated control seeds (Fig. 1). There was no significant difference in MGT between matriconditioned and control seeds after $7 \mathrm{~d}$ of aging (Fig. 1E). After $14 \mathrm{~d}$ of aging, matriconditioned seeds had a 31\% lower MGT compared with nontreated control seeds (Fig. IF).

Bermudagrass. Both 7-d and 14-d aging treatments decreased GP (Figs. 2B-C). Matriconditioned seeds had $11 \%$ (aged $7 \mathrm{~d}$ ) and 2.5-fold (aged $14 \mathrm{~d}$ ) higher final GP compared with nontreated control seeds (Fig. 2). There was no significant difference in MGT between matriconditioned and control seeds after 7 or $14 \mathrm{~d}$ of aging (Figs. 2E-F).

Centipedegrass. Interestingly, there was a higher final GP after $14 \mathrm{~d}$ of aging, whereas $7 \mathrm{~d}$ of aging reduced final GP (Figs. $3 \mathrm{~B}-\mathrm{C}$ ). Matriconditioned seeds had $40 \%$ (aged $7 \mathrm{~d}$ ) and 73\% (aged 14d) lower final GP compared with nontreated control seeds (Fig. 3). There was no significant difference in MGT between matriconditioned and control seeds after $7 \mathrm{~d}$ or $14 \mathrm{~d}$ of aging (Figs. 3E-F).

\section{Discussion}

Considerable evidence indicates that $\mathrm{MC}$ enhances final GP and the speed of germination (Khan, 1992; Taylor et al., 1998). Overall, MC increased final GP $10 \%$ to $55 \%$ compared with nontreated seeds. Similarly, MC increased the speed of germination (MGT) $20 \%$ to $65 \%$ compared with nontreated seeds (Figs. 1-3). This is in agreement with a previous report that showed that matric priming improved germination and emergence of kentucky bluegrass (Poa pratensis) (Pill et al., 1997).

It has been hypothesized that seed enhancement treatments reduce the longevity of seeds (Parera and Cantliffe, 1994; Taylor et al., 1998). We found that there was little or no decline in GP for the cultivars 'Pensacola' or 'Common'. 'Princess' seeds had a $10 \%$ decline in final GP after $7 \mathrm{~d}$ of aging. Furthermore, $14 \mathrm{~d}$ of aging showed more of a pronounced decline in GP for 'Pensacola' and 'Princess' seeds. Interestingly, 'Common' centipedegrass seeds had a higher final GP after $14 \mathrm{~d}$ of aging compared with nonaged seeds. This

Table 2. Results of analysis of variance to determine the effect of matriconditioning (MC) and aging on germination of bahiagrass, bermudagrass, and centipedegrass seeds.

\begin{tabular}{|c|c|c|c|c|c|c|c|}
\hline \multirow[b]{2}{*}{ Sources of variation } & \multirow[b]{2}{*}{ df } & \multicolumn{2}{|c|}{ Bahiagrass } & \multicolumn{2}{|c|}{ Bermudagrass } & \multicolumn{2}{|c|}{ Centipedegrass } \\
\hline & & $\mathbf{F}$ & $P>\mathbf{F}$ & F & $P>\mathrm{F}$ & $\mathbf{F}$ & $P>\mathrm{F}$ \\
\hline $\mathrm{MC}$ & 1 & 376 & $<0.0001$ & 434 & $<0.0001$ & 126 & $<0.0001$ \\
\hline $\mathrm{MC} \times$ aging & 1 & 15.1 & $<0.0001$ & 84.5 & $<0.0001$ & 123 & $<0.0001$ \\
\hline
\end{tabular}

Table 3. Comparison of regression equation parameters for germination of bahiagrass, bermudagrass, and centipedegrass as a function of time. ${ }^{\mathrm{z}}$

\begin{tabular}{|c|c|c|c|c|c|c|}
\hline \multirow[b]{2}{*}{$\underline{\text { Treatment }}$} & \multicolumn{2}{|c|}{ Bahiagrass } & \multicolumn{2}{|c|}{ Bermudagrass } & \multicolumn{2}{|c|}{ Centipedegrass } \\
\hline & Slope & $\mathbf{R}^{2}$ & Slope & $\mathbf{R}^{2}$ & Slope & $\mathbf{R}^{2}$ \\
\hline Nonaged control & $44.1 \mathrm{e}$ & 0.97 * & $63.4 \mathrm{c}$ & $0.99 *$ & $63.9 \mathrm{~d}$ & 0.97 * \\
\hline 7-d aged control & $48.6 \mathrm{~d}$ & $0.95^{*}$ & $64.6 \mathrm{c}$ & $0.97^{*}$ & $68.1 \mathrm{c}$ & 0.99 * \\
\hline 7-d aged MC & $70.1 \mathrm{a}$ & $0.97^{*}$ & $73.6 \mathrm{~b}$ & $0.98 *$ & $55.5 \mathrm{e}$ & $0.96^{*}$ \\
\hline 14-d aged control & $49.1 \mathrm{~d}$ & $0.98 *$ & $27.8 \mathrm{~d}$ & $0.99 *$ & $89.2 \mathrm{a}$ & $0.98^{*}$ \\
\hline
\end{tabular}

${ }^{\mathrm{z}}$ Germination was fit to the following equation: $y=a / 1+e^{-[X-X o / b]}$, where $y=$ germination $(\%), a=$ slope, $X_{\mathrm{o}}=$ germination elicits $50 \%$ response, $b=\mathrm{y}$-intercept, $x=$ time $(\mathrm{d})$, and $\mathrm{R}^{2}=$ regression coefficient squared.

* Significant at $P<0.001$. Means followed by different letters in the same column were significantly different at $P<0.05$. Matriconditioning (MC) refers to a seed enhancement technique using a solid carrier and water. 
result may be explained by the possibility of some other physiological mechanisms that are not analyzed in this work. A similar observation has recently been reported that primed and stored amaranth (Amaranthus cruentus) seeds showed no decline after 4 months but with a slight decline after 8 months storage (Tiryaki, 2006). Further studies are needed to evaluate the other mechanisms may be affecting aging in warm-season turfgrass seeds.

\section{Literature cited}

Association of Official Seed Analysts. 2002. Rules for testing seeds. Assn. Offic. Seed Analysts, Las Cruces, NM.

Hacisalihoglu, G., A.G. Taylor, D.H. Paine, D.B. Hilderbrand, and A.A. Khan. 1999. Embryo elongation and germination rates as sensitive indicators of lettuce seed quality. HortScience 34:1240-1243.
Hodges, A.W. and W.D. Mulkey. 2003. Economic impacts of agricultural and natural resource industries in Florida. University of Florida Institute of Food and Agricultural Sciences. Electronic Data Information Source Document FE627.

Khan, A.A. 1992. Preplant physiological seed conditioning. Hort. Rev. (Amer. Soc. Hort. Sci.) 13:131-181.

Khan, A.A., J.D. Maguire, G.S. Abawi, and S. Ilyas. 1992. Matriconditioning of vegetable seeds to improve stand establishment in early field plantings. J. Amer. Soc. Hort. Sci. 117:41-47.

Parera, C.A. and D.J. Cantliffe. 1994. Presowing seed priming. Hort. Rev. (Amer. Soc. Hort. Sci.) 15:109-141.

Pill, W.G., J.J. Frett, and I.H. Williams. 1997. Matric priming of kentucky bluegrass and tall fescue seeds benefits seedling emergence. HortScience 32: 1061-1063.
Tarquis, A.M. and K.J. Bradford. 1992. Prehydration and priming treatments that advance germination also increase the rate of deterioration of lettuce seeds. J. Expt. Bot. 43:307-317.

Taylor, A.G., P.S. Allen, M.A. Bennett, K.J. Bradford, J.S. Burris, and M.K. Misra. 1998. Seed enhancements. Seed Sci. Res. 8:245-256.

Tiryaki, I. 2006. Priming and storage of amaranth seeds: Effects of plant growth regulators on germination percentage at low temperature. Seed Sci. Technol. 34:169-179.

Trenholm, L.E., J.B. Unruh, and J.L. Cisar. 2001. Selecting a turfgrass for Florida lawns. University of Florida Institute of Food and Agricultural Sciences. Electronic Data Information Source Document ENH04. 